\title{
Poverty and Undernutrition in Nigeria: Some Programs \& Policies
}

\author{
Taiwo O. Soetan \\ Red River College \\ Winnipeg, Canada \\ E-mail: tsoetan@rrc.ca
}

\begin{abstract}
This descriptive study examined the adverse effect of the twin problems of poverty and undernutrition in Africa's largest economy and most populous country, Nigeria, following the country's return to democratic dispensation after several years of uninterrupted military rule in the country. This study considers the adverse impact and effect of poverty and undernutrition in Nigeria on Nigerians in the first eight years of return to democracy i.e. 1999-2007 after several years of uninterrupted military rule, some of the federal, state, and local governments' past efforts in terms of the programs and policies that were introduced to address poverty and undernutrition in the country, and the success or otherwise of these programs and policies.
\end{abstract}

Keywords: Nigeria, Poverty, Undernutrition, Government, Programs \& Policies,

\section{Introduction}

Poverty and undernutrition are two separate and distinct but similar economic characteristics of underdevelopment in Nigeria and the adverse effect of these twin phenomenon explains why millions of people in the most populous country and largest economy in Africa continue to live in squalor and destitution. The effects of poverty and undernutrition include but are not limited to illiteracy, ill-health, hunger, incapacity, and low life span. These also effectively denies the majority of the population from obtaining good and sound education, adequate nutrition and terminates aspirations, hopes and any enjoyment for the future.

Nigeria is the largest economy in Africa with a GDP of USD\$375.7B in 2017, and the most populous country in the continent with a population of 191.9m (World Bank, 2018). For the purpose of the period under review i.e. 1999-2007, Nigeria's population as at 2007 was put at $148 \mathrm{~m}$ (World Bank, 2008). The country has over 200 ethnic groups and two major religions i.e. Islam and Christianity. The three major ethnic groups in the country are Yoruba, Igbo, and HausaFulani. Nigeria, a former colony of the United Kingdom (U.K) attained her independence on October 1, 1960 from the U.K. Nigeria practices a presidential style of democracy like the United States. A World Bank (2018) report revealed that Nigeria has the highest GDP in Africa. The report put the country's GDP in 2016 at USD $\$ 405.1$ billion while the GDP Per Capita in same year was USD\$2,179.99. Also, a United Nations (UN, 2017) report put the country's population in 2016 at about 186 million, making the country the most populous in Africa. The report further revealed that the median age in the country was 17.9 years and there are 36 states in the country.

The research questions are based on the policies and programs that were introduced by the democratic government in Nigeria to address the issue of poverty and undernutrition during the period under review i.e. 1999-2007 and the effect of these policies on poverty and undernutrition in the country. These questions are:

1) What efforts did the democratic government make to address the issue of poverty and undernutrition in terms of policy initiatives and programs?

2) How successful were these policies and programs in addressing the problem of poverty and undernutrition in the country?

\subsection{Purpose of the Study}

The purpose of this paper is to study poverty and undernutrition in Nigeria within the period under review i.e. 19992007 when Nigeria started the present continuous democratic dispensation after about fifteen years of military rule. This study examines the past policies and programs that were introduced to address poverty and undernutrition and the success or otherwise of these policies and programs. Based on the Strategic Development Goals (SDG) of the United Nations (UN) to end extreme poverty in the world by 2030 (United Nations, UN 2015) report, and the recent classification of Nigeria as the poverty capital of the world (Kazeem, 2018), it becomes imperative to examine the poverty and undernutrition challenge in Nigeria. 


\subsection{Methodology}

A descriptive research design was adopted for this study. The data obtained for this study were mainly from the United Nations, World Bank, and the National Bureau of Statistics of Nigeria.

\section{Poverty Levels}

The UN (2008) report on human development revealed that based on 2007 estimate, 34.1 percent which represented over 50 million people of the estimated 148 million Nigeria's population according to the World Bank (2008) report live below poverty line. The UN report also revealed that 70.8 percent of the population live on less than USD \$1/day while 92.4 percent of the population live on less than USD\$2/day. Based on the two poverty lines of USD\$275 and USD \$375/year respectively according to Jay (1998), we have a situation in which the workers who earn the minimum wage earn USD \$528/year (in the period under review) which put them above the poverty and extreme poverty levels.

Based on the estimates therefore, it is safe to conclude that about 103.6 million of the populace in Nigeria that live on less than USD\$1/day which translated to less than USD\$360/year were poor during the period of review.

\subsection{Rural and Urban Poverty}

The level of rural poverty in Nigeria is still very much higher than what obtains in the urban areas due to the wide gap in terms of infrastructural provisions and standard of living. This fact was supported by the 2004 report of the National office of Statistics that revealed that about 76 percent of the poor populace reside in rural areas with the remaining 24 percent residing in urban areas.

\subsection{Undernutrition}

Nigeria has made little progress in the improvement of the well-being of its citizenry especially children whose chance of reaching their full potential continues to be cut short due to ill-health caused by under-nutrition. UNICEF (2007) report on the Nigeria Multiple Indicator Cluster Survey revealed the impact of undernutrition in children aged 5 years and below in the northern and southern parts of Nigeria alluded to this fact. Northern Nigeria is worst hit by the three anthropometric measures of nutrition compared to the southern part just as they are worst hit by levels of poverty. These three anthropometric measures are wasting, stunting and underweight (UNICEF, 2007). The report further stated that these measures also indicate child well-being because poor growth performance reveals problems of food insecurity, poor access to medical and health facilities, poor child care etc.

UNICEF (2007) averred that wasting describes a recent and severe process that has produced a substantial weight loss as a consequence of acute and recent shortage of food and/or disease within a short time span while stunting (low height for age) refers to a deficit of linear growth that has failed to reach a genetic potential due to poor diet and diseases.

\subsection{Percentage of Undernourished Children in Nigeria, 2007}

The graph in figure 1 (See Appendix below) shows that about 25.3 percent of children aged under five years old in Nigeria were underweight, 8.3 percent were severely underweight, and 34.3 percent were stunted or too short for their age. The children in the northern part of the country showed a higher level of undernourishment which was put at an average of 41 percent, stunting at 38 percent, and wasting at 10.8 percent respectively compared to their counterparts in the southern part whose levels of undernourishment, stunting and wasting were put at 17 percent, 23 percent, and 6 percent respectively (UNICEF, 2007). The report further stated that children whose mothers have a minimum of secondary education or higher have lesser incidents of underweight while children whose mothers had no education had a higher prevalence of malnutrition.

\subsection{Relationship between poverty and undernutrition}

In Nigeria, there is a close link between poverty and undernutrition. With high levels of poverty and low income, it is almost impossible for many individuals and families to get an adequate level of food and nutrient consumption. The World Bank (2006) reported that the adverse impact of undernutrition and longevity cannot be ignored. The report further stated that the impact of undernutrition on individuals includes diminishing cognitive skills, muscular strength, immunity to diseases and incapacity to do productive work.

Lipton (1983) argued that the use of calorie-based poverty line is an appropriate way of measuring moderate and extreme levels of poverty hence the relationship between poverty and undernutrition in the developing world. Also, economic challenges and poverty have an adverse impact in reducing food intake and the near collapse of nutrition oriented health delivery services in Nigeria (Igbedioh, 1993). 


\subsection{Relationship between Adequate Nutrition and Enhanced Work Capacity}

The graph in figure 2 (See Appendix below) reveals that labour markets generate income and therefore provide potential source of good health while good nutrition also have an effect on the capacity of the body to perform a productive work that generate income. Jay (1998)in the graph in figure 2argued that there is a direct relationship between enhanced work productivity and adequate nutrition as well.

\section{Effect of poverty in Nigeria}

Poverty incidents and poverty reduction are the most challenging obstacles facing Nigeria in her quest to achieve sustainable economic growth (International Monetary Fund, IMF 2005).

The IMF (2005) report further stated that poverty has been and is still a major issue confronting Nigeria since her independence in spite of her endowments with natural, human and mineral resources. Although the macroeconomic situation in Nigeria showed improvements between 2004 and 2007 (World Bank, 2008), the country continues to be faced with increasing and persistent problems of poverty and undernutrition which is attributed mainly to poor governance.

The limited data on the incidence of poverty in Nigeria in Table 1 (See Appendix below) revealed that poverty levels in urban areas showed a steady rise from 17.2 percent to 58.2 percent from 1980 till 1996, a period in which different military regimes were in government in the country for 13 years during that period. The drop to 24 percent in 2004 might be due to the efforts of the democratic government in Nigeria following a successful return to democratic rule in the country in 1999 and the macroeconomic improvements in the country (World Bank, 2008). However, the poverty levels in the rural areas in the country recorded in Table 1continued to get worse from 28.3 percent in 1980 to 76 percent that was recorded in 2004.

Although Table 1 revealed the rate of poverty in both the rural and urban areas in Nigeria, Table 2 (See Appendix below) revealed the poverty profile in rural areas of Nigeria with a higher incidence of poverty compared to the urban areas in terms of poverty gap, severity, and the percentage of the population.

In Nigeria, the effects of poverty and undernutrition vary widely and these include growth and mental retardation, reduced immunity, increased illnesses, depression, lower intellectual capacity, lack of motivation and low life expectancy (Ogbedioh, 1993; Aromolaran, 2004; Babatunde, Adejobi, \& Fakayode, 2010) and these have adverse effects on the productivity and efficiency of the labour force in Nigeria. Ray (1998) argued that because of the relationship between poverty and undernutrition, there is an established negative effect on the capacity to function effectively and work maximally in the labour force. Ray (1998) further argued that good and adequate nutrition are needed to have a productive work life, and that four main components are a necessity to achieve a productive work life. These are:

i. Energy input in which the periodic consumption of food serves as the main source of energy input into the human body

ii. Resting metabolism which represents energy needed to maintain body temperature, heart, and respiratory organ

iii. Energy needed to work since much of the activities of the poor is labour intensive which involves carrying logs, woods, pushing and pulling trucks that require significant amounts of energy, and,

iv. Storage borrowing which involves the energy deficits met by running down stores from the body and energy surplus in the body which is partly used and partly stored

A major challenge for the millions of people in Nigeria suffering from poverty and undernutrition is not how to avoid energy deficit which is almost impossible since they are undernourished but how to cope with their undernourishment since an undernourished body leads to breakdown of the body as earlier explained above.

\subsection{Poverty and Human Capital}

Adamu (2002) defined Human Capital as the abilities and skills of the human resource of a country. This suggests that human resources is a form of resources that can be acquired, built upon, and also developed. In Nigeria, it is disheartening to note that both the government and the majority of the populace except for the few wealthy families pay little or no attention to human capital development. Olaniyan (2004) revealed that the high level of poverty trends in many households could be traced to a lack of adequate education. The refusal of parents to send their children to school impedes their access to good and quality education which is a major contributor to the high levels of poverty.

For example, Ray (2000) stated that the low level of income of parents is a major reason why many parents withdraw their children from school. This low level of income of parents has also contributed to a situation where over 10.5 million Nigerian children who should be in school are out of school thus rendering Nigeria as the country with the highest number of out of school children in the world according to (BBC News, 2017). 
Furthermore, one out of every five out-of-school children in the world reside in Nigeria in spite of the fact that primary or elementary education in the country is both officially free and mandatory (UNICEF Nigeria, n.d.).

\subsection{Poverty and Household Expenditure in Nigeria}

One of the problems of poverty is that the poor may not be able to afford to share their poverty on equal basis especially where and when poverty is extreme. Table 3 (See Appendix below) reveals the expenditure profile of households in Nigeria, in 2007, that are able to provide a bed net for children aged between 0-59 months.

The National Bureau of Statistics (2005) report on poverty profile in Nigeria revealed a high degree of disparity in expenditure patterns in households. The poorest per capita expenditure was N4, 291.00 on food items and N3, 520.00 on non-food items which translated to about USD\$34 and USD\$28 respectively (National Bureau of Statistics, 2005). The report further revealed that the least per capital expenditures were N29,489.00 on food items and N39,543.00 on non-food items which was about USD \$236 and USD\$316 respectively. Urban households also expended more on both food and non-food items when compared to rural households with the urban households/capita household expenditure on non-food items almost doubling that of the rural households at N25,101.00 and N13,058.00 i.e. USD\$201 and USD\$104 respectively (National Bureau of Statistics, 2005). The report concluded that while the per capita household expenditure on food in the rural areas was N16,568.00, that of urban areas was N18,099.00 i.e. USD\$133 and USD 145 respectively. This showed that urban expenditures were still higher than rural expenditures although rural households spent a higher percentage of their income on food.

\subsection{Poverty and Agriculture}

From Table 4 (See Appendix below), it is obvious that a larger proportion of the Nigerian population that reside in rural areas with a poverty level of 76 percent was also involved in subsistence farming as an occupation. Since subsistence farming is not revenue yielding as opposed to mechanized or commercial farming, a larger percentage of these people therefore remain poor. Although the World Bank (2008) report showed that Agriculture contributed about 42 percent to Nigeria's GDP, the poor and extremely poor people were still involved in subsistence Agriculture rather than mechanized with about 86 percent of the rural dwellers in the country engaged in Agriculture as against the about 14 percent in urban areas.

The households that are above the poverty level in Nigeria are involved in non-Agricultural activities with about 37 percent of these households participating in non-subsistence Agriculture and related activities (Olaniyan \& Bankole, 2005).

\subsection{Poverty and Education}

Education does not only provide an effective way of measuring how enlightened a country is, but also the human capacity development. Literature revealed that the higher the level of education of individuals or communities, the higher their chances of living out of poverty (Olaniyan \& Bankole, 2005; Bolujoko, 2008; Olaniyan, 2004; Adamu, 2002). In Nigeria,

Saint, Hartnett, \& Strassner (2003) reported that primary education enrols 81 percent of all relevant age bracket with only 69 percent graduating. This is not encouraging when considered from the fact that the federal government through the universal basic education programme provides free and mandatory education in the primary school system in Nigeria (UNICEF Nigeria, n.d.).

Another major problem identified in Nigeria is the fact that higher and technical education are not geared towards labour market needs (Ukuma, Ochedikwu, \& Deke, 2013; Ayonmike \& Okeke, 2016; Uzor \& Nwabuikwu, 2016) and this has compelled several corporate and multinational organizations in the country mostly in the financial services, telecoms, and the oil and gas sectors to go to Europe and North America to recruit Nigerians from wealthy homes who have escaped poverty, and graduated from higher education institutions in these advanced continents on a yearly basis (Careers in Africa, 2019) to come back home and work for their organizations.

\subsection{Poverty and Gender}

Olaniyan \& Bankole (2005) argued that households having males as their head appear to be deeper in the poverty region compared to their female counterparts. As at 2004, 58.2 percent of households that have males as head were in poverty compared to 43.5 percent of their female counterparts. The result also showed a high level of illiteracy amongst the females which could be attributed to the rate of school attendance between males and females in Nigeria which was put at 54 percent to 46 percent respectively which reveals that more males are educated than females. Furthermore, Olaniyan \& Bankole (2005) averred that female-headed households are smaller in size and their educational level higher. This may have had an effect on why male headed households were deeper in poverty compared to their female counterparts. 
On average, households that are headed by females are usually between two and four persons while those that are headed by males are usually between five and nine persons (Olaniyan \& Bankole, 2005). They further stated that it is noteworthy that most female headed households are headed by widows with some form of education and households headed by persons without education are likely to be deeper in poverty. The larger the household, the higher the level of poverty too (Olaniyan \& Bankole, 2005).

\section{Efforts of Governments to reduce poverty and undernutrition:}

The United Nation's Human Development Index (HDI) is a measure of development used to establish a country's level of development and standard of living.

Table 6 (See Appendix below) reflects the efforts of the Nigerian government compared to other countries of the world to improve the country's standard of living and reduce poverty over the time period 1975 and 2005 according to the United Nations Human Development (UNDP, 2008) report.

From the data in Table 6, the development efforts of the countries identified to improve the living standards of their citizens to enable these countries to continue to experience economic growth could be gleaned. The table further revealed that according to the HDI ranking, Nigeria was placed at a dismal 154 position out of 177 countries surveyed. Other African countries like South Africa and Kenya fared better than Nigeria in the ranking although their positions were neither competitive nor enviable at 125 and 144 respectively.

\subsection{Some of the Past Programs and Policies Aimed at Alleviating Poverty and Undernutrition in Nigeria}

In this section, a list of the past efforts of the different Nigerian governments i.e. both military and democratic governments at addressing poverty and undernutrition in terms of the programs that were introduced prior to, and up till the period under review in this study i.e. 1999-2007 are identified. These programs include:

$i$. Operation Feed the Nation (OFN). The program was aimed at increasing productivity and reducing poverty among Nigerians due to the inability of the Agricultural sector of the Nigerian economy to satisfy the food needs of the country (Arua, 1982). The programme as lofty as it was, however, failed woefully because of inadequate planning and implementation (Arua, 1982; Nzeshi, 2006).

ii. The Structural Adjustment Programme (SAP). The program was an International Monetary Fund (IMF) backed initiative that was aimed at alleviating poverty and reducing the number of Nigerians in the poverty level. Igbedioh (1993) stated that the period of SAP was very harsh and austere on Nigerians and it witnessed a near collapse of nutrition health delivery services and rapid increase of poverty. The lack of palliative and human face measures in the implementation of SAP in addition to ignoring the aspect of human development led to its failure as the program ended up increasing poverty and undernutrition amongst the populace rather than reducing it (Igbedioh, 1993).

iii. NEEDS. The National Economic Empowerment Development Strategy which is the acronym for NEEDS was introduced by the democratic government in power in the period under review for this study i.e. 1999-2007. The government was headed by Chief Olusegun Obasanjo following the return to civilian rule in the country. The program was aimed at reducing poverty and undernutrition in the country (Akpobasah, 2004). The programme was a home grown development initiative that was led by the federal government at the federal level, and replicated at the other levels of government i.e. the state-SEEDS, State Economic Empowerment Development Strategy, and the local government-LEEDS, Local Economic Empowerment Development Strategy. The program was aimed at alleviating poverty significantly and its three main goals were human development, government and Institutional reform, and privatization (IMF, 2005; Akpobasah, 2004).

iv. Microfinance Banks. An offshoot of the NEEDS strategy was the establishment of microfinance banks by corporate organisations, private banks, and wealthy individuals in 2006. The microfinance banks are expected to grant loans and credit facilities to the poor and those involved in small and medium scale businesses in order to create more jobs in the country by promoting the need for less dependence on oil, encouraging modern Agricultural production rather than subsistence farming, promotion of the manufacturing sectors of the economy and thus reduce the incidence of unemployment and prevalence of poverty and undernutrition. This initiative, in addition to the other reforms taking place in the country was aimed at alleviating substantially the poverty and undernutrition level in Nigeria. Although the World Bank (2008) report revealed that the prospects of these programs at alleviating and reducing poverty were promising, there vocation of the licenses of many microfinance banks by the Central Bank of Nigeria (CBN) due to inadequate capitalization adversely affected the impact of these microfinance banks in actualizing the anti-poverty efforts for which they were established and licensed to operate in the first instance (World Bank, 2017; Agbaeze \& Onwuka, 2014; Sahara Reporters, 2018). 


\section{Conclusion:}

This study provides a tentative report of the problems of poverty and undernutrition in Nigeria during the period that was reviewed i.e. 1999 to 2007. Based on the data provided in this study, the problems of poverty and undernutrition is indeed affecting the economic potentials of Nigeria and the productivity of the country's labour force.

Poverty and undernutrition in Nigeria has been established as a serious phenomenon that is hindering the capacity of the largest economy in Africa from achieving her full potential due to their negative effect on the economy, and labour force. This study revealed that a larger percentage of the country's populace still lives in a state of serious poverty based on the data provided in this study. The failure of the different government policies that were introduced in the country, and the reasons for their failure without any doubt, have contributed significantly to the increasing levels of poverty and undernutrition in the country.

It is recommended that home-grown policies and programs that are managed by seasoned economists and technocrats, aimed at significantly reducing poverty and undernutrition in the country should be aggressively pursued in order to bring about a meaningful solution to the problems of poverty and undernutrition in Nigeria. Since this study only reviewed the problems of poverty and undernutrition between 1999 and 2007, it will be important to see if other studies will come up with similar findings if the research is extended to date and if other poverty and undernutrition alleviating programs and policies that may have been introduced beyond the period of this study have had any positive impact or not in addressing poverty and undernutrition in Nigeria.

\section{Appendix}

Figure 1.

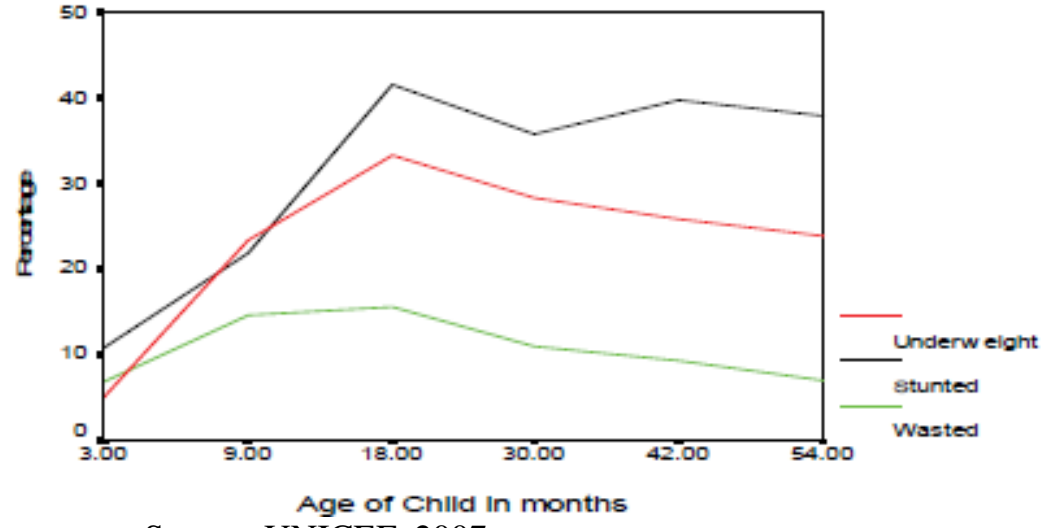

Source: UNICEF, 2007.

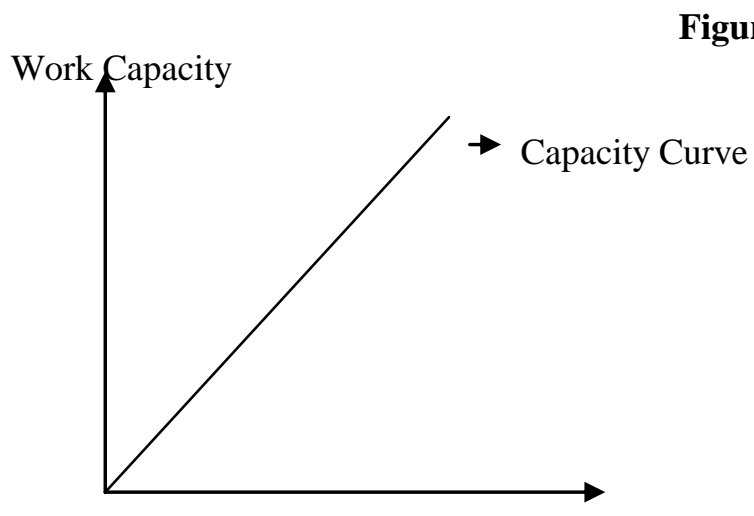

Source: Ray (1998)

Adequate Nutrition (Income)

(Please note that the curve is not straight but curved in an upward direction). 
Table 1. Rate of Poverty in Nigeria

\begin{tabular}{cccc}
\hline Year & Urban Sector \% & Rural Sector \% & Population(Million) \\
\hline 1980 & 17.2 & 28.3 & 65 \\
1985 & 37.8 & 51.4 & 75 \\
1992 & 37.5 & 46.0 & 91.5 \\
1996 & 58.2 & 69.8 & 102.3 \\
2004 & 24.0 & 76.0 & 137.8 \\
\hline
\end{tabular}

Source: National Bureau of Statistics (2005).

Table 2. Poverty Profile in Rural Nigeria

\begin{tabular}{lllll}
\hline & P0 Head Count & P1 Poverty Gap & P2 Severity & Percentage of Population \\
\hline All Rural & 0.624 & 0.299 & 0.181 & 100.00 \\
Male & 0.628 & 0.300 & 0.180 & 87.40 \\
Female & 0.600 & 0.299 & 0.187 & 12.60 \\
\hline
\end{tabular}

Source: Olaniyan \& Bankole (2005)

Table 3. Percentage of children aged 0-59 months that slept under an insecticide treated net the previous night in Nigeria, 2007

\begin{tabular}{cccc}
\hline & $\begin{array}{l}\text { Slept under } \\
\text { a bed net }\end{array}$ & $\begin{array}{l}\text { Slept under a } \\
\text { treated bed net }\end{array}$ & $\begin{array}{l}\text { Did not sleep } \\
\text { under a } \\
\text { net }\end{array}$ \\
\hline Sex & & & \\
Male & 3.8 & 3.3 & 95.4 \\
Female & 4.5 & 3.7 & 94.7 \\
Area & & & \\
Rural & 3.3 & 2.6 & 95.9 \\
Urban & 6.2 & 5.5 & 93.0 \\
Wealth Index quartile & & & \\
Poorest & 1.1 & 0.7 & 97.9 \\
Richest & 8.5 & 7.6 & 90.8 \\
\hline
\end{tabular}

Source: UNICEF 2007

Table 4. Poverty Profile in Nigeria

\begin{tabular}{|c|c|c|c|c|c|}
\hline Occupation & P0 Head Count & $\begin{array}{l}\text { P1 } \\
\text { Gap }\end{array}$ & Poverty & P2 Severity & $\begin{array}{l}\text { Proportion } \\
\text { Population }\end{array}$ \\
\hline Farming & 0.644 & 0.310 & & 0.187 & 80.90 \\
\hline Non-Farming & 0.539 & 0.257 & & 0.155 & 19.10 \\
\hline
\end{tabular}

Source: Olaniyan \& Bankole (2005)

Table 5. Poverty Profile in Rural Nigeria

\begin{tabular}{lllll}
\hline $\begin{array}{l}\text { Educational level of } \\
\text { Household head }\end{array}$ & P0 Head Count & P1 Poverty Gap & P2 Severity & Percentage of Population \\
\hline No Education & 0.669 & 0.329 & 0.201 & 67.20 \\
Primary & 0.541 & 0.237 & 0.137 & 20.80 \\
Secondary & 0.504 & 0.239 & 0.142 & 9.20 \\
Above Secondary & 0.530 & 0.252 & 0.142 & 2.80 \\
\hline
\end{tabular}

Source: Olaniyan \& Bankole (2005)

Table 6. Human Development Index Trends between 1980 and 2005

\begin{tabular}{clcccccc}
\hline HDI Rank & Country & 1980 & 1985 & 1990 & 1995 & 2000 & 2005 \\
\hline 1 & Iceland & 0.888 & 0.896 & 0.915 & 0.920 & 0.945 & 0.967 \\
3 & Canada & 0.892 & 0.915 & 0.935 & 0.941 & 0.950 & 0.965 \\
125 & S/Africa & 0.657 & 0.679 & 0.698 & - & 0.687 & 0.671 \\
144 & Kenya & - & - & - & - & 0.516 & 0.526 \\
154 & Nigeria & - & - & 0.452 & 0.456 & 0.450 & 0.494 \\
162 & Malawi & - & 0.377 & 0.386 & 0.434 & 0.445 & 0.448 \\
177 & S/Leone & - & - & - & - & - & 0.366 \\
\hline
\end{tabular}

Source: UNDP, 2008 


\section{References}

Adamu, P. A. (2002). "The Impact of Human Capital on Economic Growth in Nigeria: An Error Correction Approach". In Human Resource Development in Africa, theNigerian Economic Society - Selected papers for the 2002 Annual Conferencepp. 53-78.

Agbaeze, E. K. \& Onwuka, I. O. (2014). Microfinance Banks and Rural Development: The Nigeria Experience. International Journal of Rural Management, Vol 10(2), 147-171.

Akpobasah, M. (2004). Development Strategy for Nigeria. Retrieved on 2/2/19 from https://www.odi.org/sites/odi.org.uk/files/odi-assets/events-documents/118.pdf

Aromolaran, A. B. (2004). Household Income, Women's Income Share and Food Calorie Intake in South Western Nigeria. Food Policy, 29, 507-530.

Arua, E. O. (1982). Achieving food sufficiency in Nigeria through the operation 'feed the nation' program. Journal of Agricultural Administration, Vol 9(2), 91-101.

Ayonmike, C. S. \& Okeke, B. C. (2016). Bridging the skills gap and tacklingunemployment of vocational graduates through partnerships in Nigeria. JournalOf Technical Education and Training, Vol 8(2), 1-11.

Babatunde, R. O., Adejobi, A. O., \& Fakayode, S. B. (2010). Income and Calorie Intake among Farming Households in Rural Nigeria: Results of Parametric and Nonparametric Analysis. Journal of Agricultural Science, Vol 2(2), 135-146.

BBC News (2017). Nigeria has the 'largest number of children out-of-school' in the world. Retrieved on 2/2/19 from https://www.bbc.com/news/world-africa- 40715305

Bolujoko S.N (2008): Education and Human Capital Development in Nigeria, Retrieved on 10/7/08 from http://www.consccima neis.com/Human\%20Capital\%20Dev\%20Speech.pdf

Careers in Africa (2019). Connecting people with 500+ of Africa's top employers. Retrieved on 18/2/19 from http://www.careersinafrica.com/

Haddad, L., Ruel, M. T., \& Garrett, J. L. (1999). Are Urban Poverty And Undernutrition Growing? Some Newly Assembled Evidence. World Development, Vol 27(11), 1891-1904.

Igbedioh S.O. (1993): Undernutrition in Nigeria: Dimension, causes and remedies foralleviation in a changing socioeconomic environment. Retrieved on 7/10/08 from http://www.ncbi.nlm.nih.gov/pubmed/8414269

Institute of Development Studies (n.d.) Large data sets. Retrieved on 2/2/19 from https://debategraph.org/Details.aspx?nid=270646

International Monetary Fund, IMF (2005). Nigeria: Poverty Reduction Strategy Paper-National Economic Empowerment and Development Strategy. Retrieved on 2/2/19 from https://www.imf.org/external/pubs/ft/scr/2005/cr05433.pdf

Kazeem, Y. (2018). Nigeria has become the poverty capital of the world. Retrieved on 2/2/19 from https://qz.com/africa/1313380/nigerias-has-the-highest-rate-of- extreme-poverty-globally/

Lipton, M. (1983). Poverty, Undernutrition, and Hunger. Retrieved on 13/2/19 fromhttp://documents.worldbank.org/curated/en/892041468766760990/pdf/multi0page .pdf

National Bureau of Statistics Report (2005). Poverty profile for Nigeria. Retrieved on7/10/08 frohttp://www.nigerianstat.gov.ng/nlss/2006/survey0/outputInformation/prereport.pd f

National Minimum Wage (Amendment) Act (2000): An Act to amend the National Minimum Wage to provide for a revised National Minimum Wage and for purposes connected therewith. Retrieved on 17/2/19 from http://www.nigeria- law.org/National\%20Minimum\%20Wage\%20(Amendment)\%20Act\%202000.htm

Nzeshi, O. (2006). Nigeria: 'Why Operation Feed the Nation Failed.' Retrieved on 13/2/19 from https://allafrica.com/stories/200604120157.html

Olaniyan, O. (2004). The determinants of child schooling among poor and non-poorfamilies in Nigeria Paper presented at the African Econometric Society's annualconference held in university of Cape Town, June 30-July 3, 2004. South Africa, 2004.

Olaniyan \& Bankole (2005). Human Capital, Capabilities and Poverty in Rural Nigeria. Research report submitted to the African Economic Research Consortium(AERC), from the second phase collaborative poverty research project. Nairobi:African Economic Research Consortium.

Ray, D. (1998). Development Economics Chapter 8. Princeton University press.

Ray, R. (2000) "Child Labor, Child Schooling and Their Interaction with Adult Labor: Empirical Evidence for Peru and Pakistan." World Bank Economic Review, Vol.14(2), 347-367.

Sahara Reporters (2018). CNB Revokes Licenses of 182 Financial Institutions. Retrieved on 14/2/19 from http://saharareporters.com/2018/09/27/cbn-revokes-licences-182-financial-institutions 
Saint, W., Hartnett, T. A., Strassner, E. (2003). Higher education in Nigeria: A status report. Higher Education Policy, Vol 16(3), 259-281.

Ukuma, S., Ochedikwu, J. O. \& Deke, G. N. (2013). Revamping Vocational and Technical Education in Nigeria for Sustainable Development. Mediterranean Journal of Social Sciences, Vol 4(12), 55-59.

United Nations (UN, 2015) Report. Sustainable Development Goals. Retrieved on 2/2/19from https://sustainabledevelopment.un.org/sdgs

United Nations Human Development (UNDP, 2008) Report. Human Development IndexTrends. Retrieved on 11/12/08 from http://hdrstats.undp.org/indicators/14.html

UNICEF (2007). Nigeria Multiple Indicator Cluster Survey (MICS) Report. Monitoringthe situation of Children and Women. Retrieved on 11/12/08 fromhttp://www.childinfo.org/files/MICS3_Nigeria_PreliminaryReport_2007_Eng.pdf

UNICEF Nigeria (n.d.). Education. Retrieved on 2/2/19 fromhttps://www.unicef.org/nigeria/education

Uzor, E. \& Nwabuikwu, O. (2016). Skills Mismatch in Nigerias Labour Market: What Are the Drivers And How Can Government Bridge the Gap? Retrieved on18/2/19 from http://cseaafrica.org/skills-mismatch-in-nigeriaslabour-market-what- are- the-drivers-and-how-can-government-bridge-the-gap/

World Bank Report (2017). Nigeria's Microfinance Bank Sector: Review and Recommendations, Retrieved on 14/2/19 from https://openknowledge.worldbank.org/handle/10986/31320

World Bank Report (2006). Where is the wealth of nations? Measuring capital for the $21^{\text {st }}$ century. Retrieved on 14/2/19 from http://siteresources.worldbank.org/INTEEI/2145781110886258964/20748034/All.pdf

World Bank Report (2008). Country brief report on Nigeria. Retrieved on 7/10/08 from http://www.worldbank.org/

World Bank Report (2008). Nigeria: Poverty in the midst of plenty: The challenge of growth with inclusion. Retrieved on 7/10/08 fromhttp://web.worldbank.org/WBSITE/EXTERNAL/TOPICS/EXTPOVERTY/EXTPA/0,,contentMDK:2020 4610 isCURL:Y menuPK:435735 pagePK:148956 piPK:216618 theSitePK:430367,00.html

World Bank Report (2008). Data on poverty and Inequality. Retrieved on 7/10/08 fromhttp://web.worldbank.org/WBSITE/EXTERNAL/TOPICS/EXTPOVERTY/EXTPA/0,,contentMDK:2020 5999 isCURL:Y menuPK:435761 pagePK:148956 piPK:216618 theSitePK:430367,00.html 